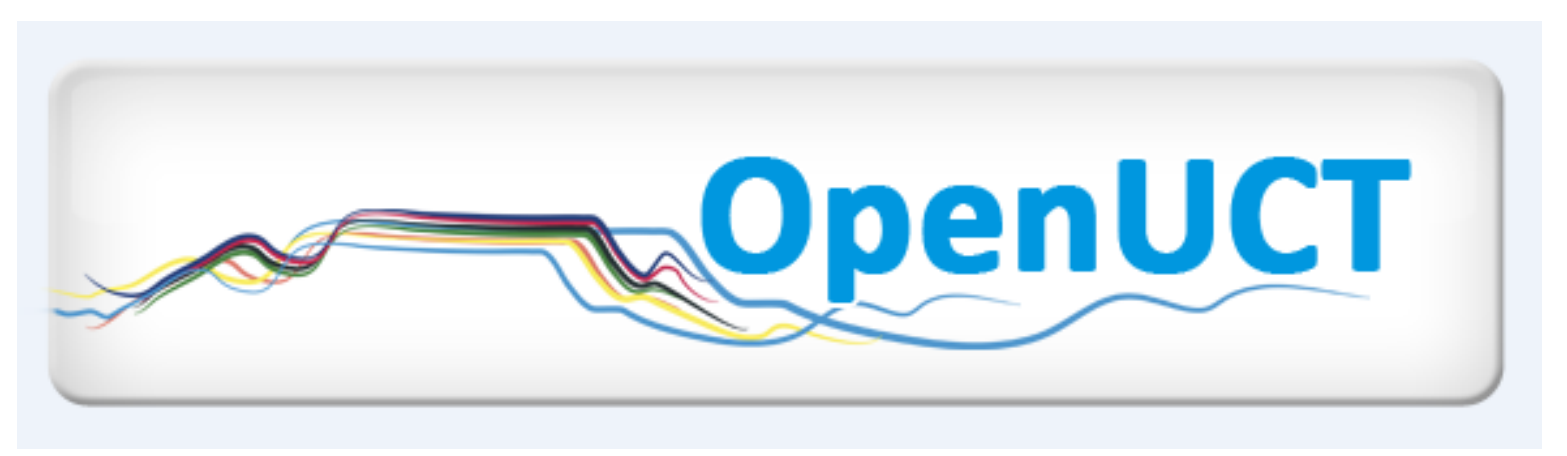

This is the author-approved manuscript version of a journal article published in:

Yeld, N. 2007. Critical questions? Some responses to issues raised in relation to the national benchmark tests project. South African Journal of Higher Education. 21(5): 610-616.

It is made available under the terms of agreement between the author and the journal, and in accordance with the University of Cape Town's Open Access Policy for the purposes of research, teaching and private study.

http://www.openuct.uct.ac.za/sites/default/files/UCTOpenAccessPolicy.pdf 


\title{
Critical questions? Some responses to issues raised in relation to the national benchmark tests project
}

\author{
N. Yeld \\ Dean: Centre for Higher Education Development \\ University of Cape Town \\ Rondebosch, South Africa \\ Email: nan.yeld@uct.ac.za
}

In 2004, the South African Universities Vice Chancellors' Association (SAUVCA) and the Committee of Technikon Principals established the National Benchmark Tests Project (Griesel 2006). Its significance is emphasised by Vice-Chancellor O'Connell $(2006,1)$ as follows:

\begin{abstract}
The project represents an attempt to provide both schooling and higher education with important information on the competencies of their exiting (in the case of schools) and entering (in the case of universities) students: information that does not duplicate the essential information delivered by the school-leaving examination, but that provides an important extra dimension.
\end{abstract}

That a good deal of confusion still exists in relation to the purposes and development trajectory of the National Benchmark Tests Project (NBTP) is evident in a recent article in this journal (Koch 2007). In this brief response to points raised in that article, I have addressed the main issues in the following categories: the purpose of the test, the timeline to implementation, the language issue, translation, and the relationship of the National Benchmark Tests (NBTs) with the soon to be introduced National Senior Certificate (NSC) examinations.

\section{THE PURPOSE OF THE TEST}

In the opening paragraph, it is stated that the test is designed 'for selection and placement' (Koch 2007, 102). This is not in fact the case: in none of the numerous written reports, publications, and presentations, is selection mentioned as a purpose of the tests. They are designed primarily as a placement measure, and are designed to achieve this through providing additional, not alternative information.

This distinction is crucial: as Koch correctly points out, the admissions tests (such as the Alternative Admissions Research Project tests) developed in the 1980s and beyond aimed to widen access by identifying talented students from poor schools, whose 'matric' results would not reveal their ability to succeed in higher education, given appropriate educational provision. The test information was therefore used as an alternative to matric scores. The NBTs, in contrast, are designed to be used in addition 
to NSC results, to assist higher education institutions to understand the meanings of the results, with the aim of helping institutions to place students onto appropriate curricular provision such as extended or augmented programmes, or remedial language courses. An example of the kind of broad information follows, extracted from NBTP presentation slides: 'Students achieving $\mathrm{X} \%$ or more would be deemed to be prepared for entry to regular degree study, providing they have met the FETC requirements stipulated by the institution/sector'.

Koch states that 'she is not sure that the original purpose of admissions testing in the South African context, namely to increase access, is in actual fact, the purpose of this new test' (ibid, 103). Koch is correct, this is not the purpose of the new test, and never has been. The purpose is to assist institutions in appropriately placing students entering higher education, so that the appalling dropout rates, and worryingly low throughput rates, are addressed through meeting students' educational needs.

Indeed, this purpose is very clearly captured by Koch as follows:

... the purpose of the test can be formulated as needing to provide information about these entry-level skills in addition (or in contrast?) to the information that we get from the schooling system, because of concerns about this system and the index used in this system (ibid, 103).

While of course it is true that any test could be used for exclusion (as is certainly and massively the case with the current Senior Certificate and will be the case with the new NSC), this is not, as Koch admits, necessarily the case with the NBTs. In perhaps the clearest indication that she does in fact understand the primary purpose of the test, she states:

The test may also be used to identify students who, even though they are admitted based on the results on the NSC, are in need of further development in certain crucial areas, for example, academic literacy or mathematical skills. In such a scenario the test will not be an admissions test, but a placement test (ibid, 104).

The last point that needs to be raised in relation to the purpose of the test concerns the contradictions apparent in the article: what is one to make of the following two statements or questions?

- Have later developments, as reflected in the press releases of December 2004 (HESA 2004), formulated a clear commitment to placement and access only, as opposed to selection? (ibid, 104)

- Rigorous research is of the utmost importance, especially if the main motivation for the test has moved from increased access to selection and exclusion (ibid, 105).

It is not clear to the reader whether Koch believes the purpose used to be selection but is now placement (the implication of her first statement) or whether it used to be increased access and has now become selection (her second statement). In addition, it 
is somewhat puzzling that 'rigorous research' is only necessary for one purpose, but be that as it may. The purpose of the test is placement into appropriate and responsive curricula and curricular routes.

\section{THE TIMELINE TO IMPLEMENTATION}

Koch raises several concerns about the time needed to develop a reliable and valid test. These are fully endorsed by the NBTP team, as can be shown in Table 1, where ' $X$ ' marks the stage which the project has reached. This table has been discussed at numerous fora.

Table 1: NBTP implementation time-line

\begin{tabular}{|l|l|l|l|}
\hline & \multicolumn{2}{|l|}{ Research phase } & \\
\hline Planning & $\begin{array}{l}\text { Test development (trails, } \\
\text { simulations) }\end{array}$ & $\begin{array}{l}\text { Development, trailing, } \\
\text { etc. in authentic context }\end{array}$ & Implementation \\
\hline 2005 & $\begin{array}{l}2006--2007 \\
X\end{array}$ & $2008--2010$ & 2011 \\
\hline
\end{tabular}

It can be seen that implementation is planned only from 2011, when the tests will have been validated. From the beginning of 2008, the tests will be written at selected institutions during registration week (incidentally making it impossible for the results to be used for selection, since the students will already have been admitted).

\section{THE LANGUAGE ISSUE}

Koch states that students '. . . have to demonstrate that they have developed the necessary literacy skills, but in their second language' (ibid, 106). A couple of points need to be made here:

- We would restate the sentence as follows: students '. . . have to demonstrate that they have developed the necessary literacy skills to perform in that language in the criterion situation (higher education study), irrespective of whether this is in their second language or not'. We argue that until such time as higher education institutions use languages other than English and Afrikaans as languages of instruction, it is pointless to assess students on their ability to undertake formal academic tasks in other languages.

- The NSC is written in English or Afrikaans only, and it is a pity that Koch does not direct her energies and research resources to this mass examination, in which the overwhelming majority of students also have to perform in their second language. The NSC will undoubtedly play a far bigger gate-keeping role in terms of candidates' life chances and choices than even her worst suspicions of the NBTs. 
In a somewhat confusing series of assertions, Koch ascribes the poor matric performance of many second language speakers, almost all of whom are speakers of English as a second or additional language (referred to here as EL2 speakers) writing 'matric' in English, to problems with assessment - that is, to problems with what she calls 'the certificate' - rather than to problems with the schooling undergone by the vast majority of students. However, it must be recognised that the results reflect educational opportunities, not simply the fact that the examination is in English. The fact that the Model C EL2 learners cited by Koch performed better than did EL2 learners from exDET schools (the numbers of students in these samples are not given) must surely be a schooling issue, not a language one, since both groups are EL2? Indeed, data from the Western Cape Education Department's Learner Performance Assessments - written by Grade 3 learners in their home languages - demonstrate very clearly the impact and influence of schooling: learners from poorer schools perform (in their home language) very much more poorly than learners in advantaged schools.

What does need to be undertaken, and will be, in the design and standard-setting process of the tests, is to ensure that test performance, holding the educational variable constant, does not differ according to home language. Two examples make this point:

- Let us take the imaginary case of Balelaking Senior Secondary, a school with 100 Grade 12s. Say that 33 of these students speak English, 34 Xhosa, and 33 Zulu, as home languages. In the NBTP piloting, it would need be ensured that these language groups performed comparably on items in the test, matched on educational background (if the Xhosa speaking group consistently outperformed the other groups in their school subject assessments, however, we would expect them to outperform them also on the NBTs).

- Take the (again hypothetical) case of Primovail Senior Secondary, a very poor school that has produced only 1 student with Senior Certificate endorsement over the last few years. All of Primovail's learners are Xhosa home language speakers. It is quite pointless to insist that Primovail Senior Secondary students should perform at the same level on the tests as Balelaking students, traditionally a top feeder school for the local university, simply because Primovail's learners are all Xhosa home language speakers.

Despite the absurdities implicit in these examples, this is essentially Koch's position: that is, if Learner 1 does more poorly than Learner 2 on the test, and Learner 1 is an EL2 speaker and Learner 2 an EL1 speaker, the differences in performance can entirely be ascribed to language background.

\section{TRANSLATION}

Should HESA decide that translation into the other language of instruction in higher education (Afrikaans) is desirable, it was agreed in 2006 that the translation of items 
will be outsourced to Stellenbosch University who will lead this process. Further, it has been agreed that internationally accepted translation protocols (including back translation) will be followed.

\section{RELATIONSHIP WITH THE NSC}

The importance of the Senior Certificate examination in the South African schooling system has been repeatedly highlighted in papers emanating from the NBTP and the AARP and other admissions projects (for example, see Badsha et al. 1994; Barsby, Haeck and Yeld 1994; Dawes, Yeld and Smith 1999; Griesel 1999 and 2006; Taylor 1999; Yeld 1995, 2001, 2006; Yeld and Haeck 1997; Yeld and Von Bommel 1997; Zaaiman 1998). This importance relates both to its role (via Umalusi) as quality assurer in the virtual absence of other mechanisms at this level (Taylor 1999), and to its motivational role for learners and educators alike.

Nevertheless, the situation remains that a new certificate, the NSC, is being introduced with the following features (to choose only three), which will make the interpretation and understanding of results extremely difficult: no Higher/Standard Grade differentiation, three totally new subjects, and no piloting.

The assumption that higher education institutions should rely on this one, untried, innovative new certificate for all its information on incoming students is not defensible, in our view, nor in the view of educational and assessment specialists more generally, who hold that, ideally, selection, monitoring and certification functions should be performed by different tests (e.g. Taylor and Vinjevold 1999, Resnick and Resnick 1992). Indeed, at the July 2007 conference of the South African Mathematics Society, in response to the voiced concerns of a number of heads of university Mathematics Departments, Ms Penny Vinjevold (Deputy Director-General, Department of Education) suggested that, given the introduction of the new NSC, it was clearly important for the Higher Education sector to have its own assessment instrument(s) in order to assist it in interpreting NSC results - in her view the NBT project would provide this and was a welcome initiative.

Finally, Koch questions why the energies expended on the NBTP were not rather put towards developing the NSC. Setting aside the enormous contributions made by HESA throughout the development of the NSC, since the NBTs are designed to assist in assessing the critical cross-cutting curriculum outcomes of the NSC offerings, the work done with schools and teachers from around the country (through their involvement in NBT test development workshops) contributes very directly to their understanding of these outcomes, and thereby to their teaching and learning. It is therefore not correct to imply that little work has been done on supporting the NSC.

The first prize for the country is a credible, effective, educationally sound schoolleaving certificate, and we believe the NBTP will contribute to its achievement. 


\section{REFERENCES}

Badsha, N., H. Griesel, M. Smith and N. Yeld. (Eds.). 1992. Proceedings of Cintsa Admissions Symposium. Cape Town: University of Cape Town.

Barsby, T., W. Haeck and N. Yeld. (Eds.). 1994. Accountability in testing: the Contribution of tests to increased access to post-secondary education. South African Association for Academic Development - Workshop Publication Series No. 2. Cape Town; University of Cape Town.

Dawes, P., N. Yeld and M. Smith. 1999. Access, selection and admission to higher education: Maximising the use of the school-leaving examination. South African Journal of Higher Education 13 (3): 97-104.

Griesel, H. 1999. Access and the higher education sector. A South African case study on innovative policy and programmes. Pretoria: Association for the Development of Education in Africa (ADEA) and South African National Department of Education.

- (Ed.). 2006. Access and entry level benchmarks: the national benchmark tests project. Pretoria: Higher Education South Africa. ISBN: 0-9585086-5-8.

Koch, E. 2007. Critical questions about the new entrance test for higher education. South African Journal of Higher Education 21 (1): 102-111.

O'Connell, B. 2006. Preface. In Access and entry level benchmarks: the national benchmark tests project, ed. H. Griesel. Pretoria: Higher Education South Africa. ISBN: 0-9585086-5-8.

Taylor, N. 1999. Learning outcomes: How will we know them? In Getting learning right. Report of the President's Education Initiative Research Project, eds. N. Taylor and P. Vinjevold, 185-204. Johannesburg: Joint Education Trust.

Taylor, N. and P. Vinjevold. 1999. Teaching and learning in South African schools. In Getting learning right. Report of the President's Education Initiative Research Project, eds. N. Taylor and P. Vinjevold, 131-162. Johannesburg: Joint Education Trust.

Resnick, L. B. and D. P. Resnick. 1992. Assessing the thinking curriculum: New tools for educational reform. In Changing assessments. Alternative views of aptitude, achievement and instruction, eds. B. R. Gifford and M. C. O'Connor, 37-75. Boston: Kluwer Academic Publishers.

Yeld, N. 1995. The school-leaving examination as a regulatory mechanism for access to post-secondary education: Possible developments and consequences. Paper Commissioned by the Access and Admissions Task Group of the National Commission on Higher Education.

- 2001. Assessment, equity and language of learning: key issues for higher education selection in South Africa. Ph.D. thesis. University of Cape Town.

- 2006. Looking backwards: a way to take diagnostic testing forward? In Improving student learning through assessment, ed. E. Rust, 32-52. Oxford: The Oxford Centre for Staff and Student Development. ISBN: 1873576730.

Yeld, N. and W. Haeck. 1997. Educational histories and academic potential: Can tests deliver? Assessment and Evaluation in Higher Education 22 (1): 5-16.

Yeld, N. and L. van Bommel. 1997. Are we playing games with the matric? Cape Argus, 17 April 1997.

Zaaiman, H. 1998. Selecting students for mathematics and science. The challenge facing higher education in South Africa. Pretoria: Human Sciences Research Council. 